\title{
Para além das Vidas Secas, resistência: linguagem-poder ${ }^{1}$ In addition to the Dry Lives, resistance: language-power
}

\author{
Teodulino Mangueira Rosendo*
}

\begin{abstract}
RESUMO: O artigo reflete sobre a linguagem na interação humana como espaço de observação e de relações de sentidos. Assim, foram caracterizados os usos da linguagempoder, abordando a partir do clássico Vidas Secas aspectos histórico e cultural do nordestino na perspectiva da resistência pelo viés da luta social e os ecos dessa obra literária no contemporâneo, através da releitura por alunos sertanejos do ensino médio. Pelas noções da Análise de Discurso de linha francesa analisou-se duas materialidades desenvolvidas no Projeto Seca, Xote e Baião, fotografia e poesias. Concluiu-se que as estruturas do poder estão na base da linguagem e submetem o indivíduo usuário da língua a regimes que se alternam em prisão e liberdade e que a resistência a seca e suas implicações se dão para além da sobrevivência, como um gesto de subjetivação política, poder maior contra qualquer dominação, bem como que os sentidos produzidos pela paráfrase caracterizaram um acontecimento enunciativo, em que o sujeitoaluno enunciador mobilizou a memória como pré-construído alcançando a produtividade.
\end{abstract}

PALAVRAS-CHAVE: Linguagem. Poder. Vidas Secas. Resistência.

\begin{abstract}
The article reflects on language in human interaction as a space of observation and relations of meanings. Thus, the uses of language-power have been characterized, approaching from the classic Vidas Secas historical and cultural aspects of the Northeastern in the perspective of resistance by the bias of the social struggle and the echoes of this literary work in the contemporary, through the re-reading by sertanejos students, high school. From the notions of French Speech Analysis, two materialities developed in the Seca, Xote and Baião Project, photography and poetry were analyzed. It was concluded that the structures of power are at the base of language and subject the individual user of the language to regimes that alternate in prison and freedom and that resistance to drought and its implications are given beyond survival as a gesture of subjectivation Politics, greater power against any domination, and that the senses produced by paraphrase characterized an enunciative event, in which the enunciating student-subject mobilized the memory as preconstructed reaching productivity.
\end{abstract}

KEYWORDS: Language. Power. Vidas Secas. Resistance.

\section{Introdução}

A reflexão sobre a linguagem na interação do sujeito, sua história e ideologia crescentemente ocupa novos espaços em trabalhos de pesquisas e promove a construção de conhecimento articulado sobre o discurso, lugar de se perceber o homem produzindo sentidos. Intenciona-se nesse artigo caracterizar o uso da linguagem-poder, a partir da obra literária Vidas

\footnotetext{
${ }^{1}$ Artigo produzido a partir das vivências do Projeto Seca, Xote e Baião desenvolvido no ano de 2012, com alunos do alto sertão paraibano.

* Universidade Sul do Santa Catarina.
} 
Secas. Assim, destaca-se elementos dessa linguagem que constituem a história e a cultura do nordestino, pela perspectiva da resistência e pelo viés da luta social, e se observa os ecos da obra Vidas Secas no contemporâneo, através da sua releitura por alunos do ensino médio.

Muitos são os estudos acerca das obras de Graciliano Ramos que almejam refletir e sentir a forma como o romancista abordou o sertão, apresentando ao leitor personagens como fazendeiros, vaqueiros, empregados, políticos, dentre outros, sendo contextualizado o Nordeste como espaço castigado pela seca e pelos dramas dela decorrentes (a exemplo do êxodo, fenômeno que ainda leva contingentes migratórios a buscarem lugares que assegurem melhores condições e digna sobrevivência). Essas narrativas de vidas sugerem constante superação de desafios, numa luta em que a resistência se ergue como bandeira na busca por direitos.

Dessa forma, numa leitura primária para o levantamento de hipóteses sobre o tema que se pretende trabalhar, entende-se que Ramos conduz os leitores - sobretudo na obra Vidas Secas em discussão - a refletir sobre diversas áreas da condição humana, convidando-os a acompanhar o caminho da evolução de suas obras, na pretensão de absorver as razões que as fizeram se tornar tão significativas na literatura brasileira. Graciliano Ramos apresentou ao povo brasileiro, a realidade difícil do convívio com a seca e suas mazelas, fazendo, pelas diversas semelhanças dos seus personagens, denúncia das situações de exclusão e abandono do povo nordestino na década de 30, traço que permeia toda a obra Vidas Secas, com elementos singularizados e constitutivos do discurso que situa historicamente, socialmente e culturalmente esse povo.

Acrescenta-se que o presente artigo está estruturado em quatro seções: Pressupostos teóricos, a obra Vidas Secas no espaço literário, resultados alcançados pela análise e considerações finais.

\section{Pressupostos teóricos / linguagem-poder}

Não seria redundância acentuar que desde a sua fundação a sociedade é política e que já nasceu dividida, como explicitado na obra Política de Aristóteles, quando afirma que o homem é um animal político por que tem voz na polis, ou seja, a partir dessa visão pode-se pensar o mundo desmembrado em dois: os que têm "voz" e os que não têm "voz". Nessa compreensão falam aqueles que podem dizer o certo e o errado em contraponto aqueles cuja fala não tem "sentido", ou legitimidade. 
O problema dessa classificação é, sobretudo, a naturalização das coisas, os rótulos construídos pela linguagem para distinguir grupos socialmente marcados e identificados numa relação de submissão, como menciona Levi Strauss (2004), que essa maneira de se rotular o que é ser humano marca fortemente a questão do não humano. Afinal é perceptível que nessa naturalização não há espaço para o questionamento.

Nessa relação, teríamos desenhado a figura do humano naquele indivíduo que possui logos, palavra, razão, o que comanda pela inteligência, porque é senhor, e por outro lado a caricatura do não humano, aquele que apenas tem som, mas não voz e, portanto, submisso, feito para o trabalho.

Nas palavras de Rancière (1996): [...] a falsa continuidade do útil ao justo vem denunciar a falsa evidência da oposição tão incisiva que separa os homens dotados de logos dos animais limitados unicamente ao instrumento da voz (phoné).

Assim, segundo Rancière, a inferência sobre as qualidades do animal lógico e do político esconde a falha do útil e do justo, havendo uma separação do corpo social a que pertence os dois. Essa relação deixa transparecer o caráter de dominação, que tenciona a luta de classes como pano de fundo, igualmente o não reconhecimento dos outros seres falantes que, sem a necessária competência, são responsabilizados pela desordem causada no logos.

Noutro viés, o autor aponta para o fato de a contradição entre animais políticos e fônicos não formar a base fundadora da sociedade política, mas um jogo de interesses presente na própria constituição da política. No entanto em Platão tem-se colocado o dano da multiplicação do povo a quem chama de seres falantes anônimos, sendo afetada a ordem dos corpos em comunidades. Nessa relação há os que são visíveis e os que não se deixam notar, são rejeitados pela ordem social, justifica Rancière:

Mas inversamente "povo" é o nome, a forma da subjetivação, desse dano imemorial e sempre atual pelo qual a ordem social se simboliza rejeitando a maioria dos seres falantes para a noite do silêncio ou o barulho animal das vozes que exprimem satisfação ou sofrimento. (RANCIÈRE, 1996, p. 36 grifos do autor).

O desenvolvimento desse princípio é pensado a partir do posicionamento dos corpos na sociedade, como revela Rancière: "[...] aqueles a quem se vê e a quem não se vê, os de quem há um logos [...] e aqueles cuja voz, para exprimir prazer e dor, apenas imita a voz articulada" (RANCIÈRE, 1996, p. 36). Este recorte está voltado para a intensificação da noção do não 
humano, "não tendo logos, não existem" (RANCIÈRE, 1996, p. 36). Na perspectiva daquele que possui o phoné, apenas imita, produz ruído, mas é desprovido de qualquer razão.

É fundamental perceber que os caminhos da linguagem, indo para além do senso comum e, portanto, sendo desnaturalizada, vai construir novas acepções tomadas como um dispositivo não dado e não transparente. Dessa forma, a partir do século XIX a linguagem se dobra sobre si mesma, se torna objeto do conhecimento da Linguística, sendo o próprio acontecimento, e os seres humanos passam a ser interpretados como sujeitos que edificam no mundo seu espaço na relação com o outro, por meio da linguagem.

Sobre a teoria da linguagem, o linguista Hjelmslev (1975 apud JAKOBSON, 2005) afirma que:

[...] a linguagem é inseparável do homem, segue-o em todos os seus atos", sendo "o instrumento graças ao qual o homem modela seu pensamento, seus sentimentos, suas emoções, seus esforços, sua vontade e seus atos, o instrumento graças ao qual ele influencia e é influenciado, a base mais profunda da sociedade humana". (JAKOBSON, 2005, p. 64).

Em verdade, a linguagem possibilita ao homem "ver" e "sentir" o mundo e os objetos que os cercam, produzindo sentidos e relações de dominação e/ou de subordinação. Assim, a maneira como esse indivíduo enxerga as coisas evidencia essas posturas e estrutura certa visão que é fruto de um mundo interior construído na/pela linguagem, com desdobramentos e encadeamentos que o farão na sociedade senhor ou escravo, um humano dentro de um poder difuso que inclui pela exclusão, contido ou repelido por ele, de direito ou apenas de deveres.

Aqui, é preciso esclarecer que a estrutura de poder que se cria na/pela linguagem, não resulta de uma escolha do indivíduo, mas exatamente o oposto, ela se dá pela imposição e exclusão social, inscrevendo-se na ordem do político.

Corroborando com essa discussão, Barthes (1996) afirma:

A "inocência" moderna fala do poder como se ele fosse um; de um lado aqueles que o têm, de outro, os que não têm; acreditamos que o poder fosse um objeto exemplarmente político; acreditamos agora que é também um objeto ideológico, que ele se insinua nos lugares onde não o ouvíamos de início, nas instituições, nos ensinos, mas em suma que ele é sempre uno. (BARTHES, 1996, p. 11, grifo do autor).

Nesse sentido, Barthes (1996) aponta para além do político, o ideológico, os dois ditam de um lugar de poder o que é legítimo, e o que é marginal, fazem ecoar as vozes "autorizadas" 
que formam o jogo do poder e lhes são fiéis, que são seguidores do seu discurso, segundo o autor um discurso sempre de arrogância. Tem-se mencionado aí o pensamento de que em todo e qualquer discurso o poder está atrelado, ainda que produzido por um indivíduo que "esteja fora dele", indivíduo a quem falta à legitimidade dos dizeres por que partem de lugares externos aos centros de domínio.

O poder da linguagem se revela pela língua, como diz Barthes (1996): "a linguagem é uma legislação, a língua é seu código". Este é um poder infindo, contra o qual se tem lutado historicamente, e que perdura insistentemente nos gestos opressores de preconceitos e estereótipos pelo uso da língua, nas palavras de Barthes (1996), "esse objeto em que se inscreve o poder, desde toda eternidade humana é a linguagem - ou, para ser mais preciso sua expressão obrigatória, a língua”.

Nessa perspectiva, a função constitutiva, paradoxalmente maléfica, da linguagem-poder é constatada nas relações cotidianas de engodo, influência, persuasão. São relações que atuam sobre o indivíduo dominado na forma de um saber verdade, legitimado por uma sociedade cujas bases estão fincadas nas relações sociais de produção e na ideologia, bases sobre as quais Marx (2003) fundamenta o seu materialismo histórico.

Noutro ponto, numa referência a língua como código a serviço da linguagem, Barthes (1996, p. 12) afirma: “[...] Não vemos o poder que reside na língua, porque esquecemos que toda língua é uma classificação, e que toda classificação é opressiva: ordo quer dizer, ao mesmo tempo, repartição e cominação [...]". Essa declaração aponta para um poder enraizado na língua, poder difuso que se dá na classificação e opera sempre como um contra, reforçando a existência de um outro, quase sempre marginalmente tratado, afinal se vive em um sistema sociolinguístico estruturado pelo poder e, portanto, escapar dessa lógica, romper com ela tem seu preço.

Tendo em vista esse panorama que se descortina pelo uso da língua, cabe destacar em Barthes (1996) a posição do indivíduo, mesmo que inconscientemente a serviço de um poder, enunciando que: [...] "em cada signo dorme este monstro: um estereótipo: nunca posso falar senão recolhendo aquilo que se arrasta na língua" [...] (BARTHES, 1996, p.15). O fato exposto traduz o paradoxo causado pelas estruturas do poder presentes na linguagem, buscando por ela se manter e a condição do indivíduo que ao tomar a língua se faz ora mestre, ora escravo à disposição de algum poderio; indivíduos que vivem a ligação entre servidão e poder. Se 
enquanto usuários têm o poder de uso da língua, mas se escravizam por se submeterem as suas exigências e normas.

Nas palavras de Barthes (1996):

$\mathrm{Na}$ língua, portanto, servidão e poder se confundem inelutavelmente. Se chamamos de liberdade não só a potência de subtrair-se ao poder, mas também e sobretudo a de não submeter ninguém, não pode então haver liberdade senão fora da linguagem. Infelizmente, a linguagem humana é sem exterior: é um lugar fechado. Só se pode sair dela pelo preço do impossível [...] (BARTHES, 1996, p.16).

Assim, fica registrada a briga de Barthes com a linguagem, dado que dela emana a criação dos estereótipos, cristalizados também pela dóxa (senso comum). A língua trabalhada pelo poder se apresenta pura e transparente a serviço dos seus súditos, e não oferece fora da sua estrutura outro lugar que seja distante dessa realidade, negando mesmo que este lugar exista. Em face desse debate sobre a linguagem, na obra Rumor da Língua, Barthes (2004) reporta-se a ela como um espaço de guerra. Uma guerra entre classes, diferenciadas pelo fato de algumas utilizarem certos idioletos que marcam um uso individual de uma variante desprestigiada socialmente e tratada de forma subalterna pelo estatuto da verdade preconizado pela ciência.

Para a ciência, a linguagem não passa de um instrumento, que quer tornar transparente, tão neutro quanto possível submetido à matéria científica (operações, hipóteses, resultados) que, ao que se diz, existe fora dela e a precede: há por um lado e primeiro os conteúdos da mensagem científica, que são tudo; por outro lado e depois, a forma verbal encarregada de exprimir esses conteúdos, que não é nada [...]. (BARTHES, 2004, p. 4, grifos do autor).

São esses estatutos da verdade que dizem que a linguagem é neutra, disfarçam que ela não é um discurso elaborado para servir ao poder, estabelecendo sentidos de dominação históricos e ideologicamente perpetuados. Mas essa condição de neutralidade é combatida pelo autor, valendo-se da literatura como artifício de liberdade, possibilidade única de se combater a língua no interior da própria língua, forma de trapaceá-la, sem ser prisioneiro das suas regras, nesse sentido declara: “[...] só resta, por assim dizer, trapacear com a língua, trapacear a língua”. (BARTHES, 1996, p. 16).

Desse modo, na ideia do autor, burlar a língua pela literatura permite ouvi-la de "fora do poder", como forma de revolução da linguagem, uma fenda que traz de volta certa independência, outrora negada. "[...] Politicamente, é ao professar e ao ilustrar que nenhuma 
linguagem é inocente, é ao praticar o que se poderia chamar de "linguagem integral" que a literatura é revolucionária”. (BARTHES, 2004, p. 5, destaque do autor).

Assim, é fundamental notar o aprofundamento que faz Barthes (2004) quanto ao uso de uma variante de língua chamada de idioleto, e que reduz a forma de expressão de indivíduos de determinadas regiões geográficas. Estas variações (gírias, jargões, dentre outras) levam o autor a avançar para uma especificação social desses diferentes usos, a que chama de socioletos e designar, nesse neologismo, uma classe de indivíduos coletivamente filiados a estes dizeres:

É tempo de dar um nome a essas linguagens sociais recortadas na massa idiomática e cuja estanqueidade, por mais que a tenhamos sentido, de início, como existencial, acompanha, através de todas as trocas, todos os matizes e as complicações que é lícito conceber, a divisão e a oposição das classes; chamemos essas linguagens de grupo de socioletos (por oposição evidente a idioleto, ou falar de um indivíduo). (BARTHES, 2004, p.125).

Finalmente, o autor assinala que nessa divisão da linguagem, nesse recorte social, sobressai a luta de classes e o lugar de resistência de onde incessantemente parcelas de indivíduos falam engajados, pela palavra, pela prática de seu exercício no mundo, e se constituindo humanos, inscritos na ordem do político. Como afirma Deleuze (2011), na obra Mil Platôs, linguagem é política. Se fala porque se é um ser político, se fala por estar permeado de poder, numa relação de mando e de obediência.

\section{Sobre literatura e vidas secas}

A mobilização da relação língua, linguagem, ideologia e sujeito tem permeado este trabalho reflexivo sobre a linguagem, e mostrado os elementos característicos do discurso, tomando esta palavra numa acepção que a distância do modo como a teoria da comunicação a apresenta. Aqui discurso não é mera transmissão de uma dada informação, pensada a partir de uma linearidade entre um falante e um ouvinte (emissor e receptor), mas uma conexão entre sujeitos constituídos pelo histórico e pelo social. Conforme Orlandi: “As relações de linguagem são relações de sujeitos e de sentidos e seus efeitos são múltiplos e variados. Daí a definição de discurso: o discurso é efeito de sentidos entre locutores" (ORLANDI, 2015, p. 20).

Nesses termos, a literatura abrangendo as forças de liberdade, como diz Barthes (1996) realiza um trabalho de deslocamento sobre a língua, assumindo muitos saberes e se colocando como realista: “[...] ela é a realidade, isto é, o próprio fulgor do real” (BARTHES, 1996, p. 18). 
Ela funciona como uma engrenagem que media e confronta esta realidade pela linguagem, e um exemplo dessa configuração é a obra Vidas Secas de Graciliano Ramos.

Segundo Abel (1999), nesse clássico literário da década de 30 é possível notar o nordeste de maneira intrínseca, uma vez que muitas experiências vivenciadas pelo autor ocorreram precisamente nesse espaço.

Mas que espaço é este?

O Nordeste é um lugar conhecido como polígono das secas, pela Lei 175/36 (emendada em 1951 pela Lei 1.348) entendida como uma área formada por diferentes zonas geográficas com distintos índices de aridez e submetida a repetidas crises de prolongamento das estiagens, pelas poucas influências de massas de ar úmidas e frias vindas do Sul, predominando massas de ar quente que não geram as precipitações pluviométricas. Por outro lado, a seca também se inscreve na problemática socioeconômica, tanto quanto nas questões meteorológica descritas.

Segundo Abel (1999), a vivência nessa geografia foi uma rica fonte de alimento para o desenvolvimento das ideias de Ramos sobre a condição social e cultural da população nordestina, oprimida à época pela fome e miséria, vulnerável à intensa desigualdade social. Assim, a obra retrata a vida de Fabiano (personagem), mas também do próprio Graciliano Ramos nascido nessas paisagens; obra de valor histórico, atemporal e conduzida por um fio ideológico de denúncia e indignação, sublinhando os aspectos da dominação e da obediência, como consequência de um meio excludente, de uma linguagem-poder política que reverbera palavras de ordem, afinal como profere Deleuze e Guattari, (2011):

[...] A linguagem não se encontra em ir de um primeiro a um segundo, de alguém que viu a alguém que não viu, mas vai necessariamente de um segundo, a um terceiro, não tendo, nenhum deles, visto. É nesse sentido que a linguagem é transmissão de palavra funcionando como palavra de ordem [...] (DELEUZE; GUATTARI, 2011, p. 140).

Na obra Vidas Secas aparece à dificuldade dos personagens em manifestar aos outros ideias, pensamentos, sonhos, necessidades. Suas falas são tomadas como ruídos, numa condição de escravos da língua.

Contrariamente a esta percepção social da produção de ruído (fala), Rousseau (1978) diz:

A linguagem está sempre à nossa volta, sempre pronta a envolver nossos pensamentos e sentimentos, acompanhando-nos em toda a nossa vida. Ela não 
é um simples acompanhamento do pensamento, "mas sim um fio profundamente tecido na trama do pensamento", é "o tesouro da memória e a consciência vigilante transmitida de geração a geração". A linguagem é, assim, a forma propriamente humana da comunicação, da relação com o mundo e com os outros, da vida social e política, do pensamento e das artes. (ROUSSEAU, 1978, p. 198).

Impiedosamente, Fabiano e seus familiares retirantes são vítimas não apenas da seca, ou das condições sociais econômicas, causa primeira e fundante da obra de Graciliano Ramos, mas também lhes falta o controle dessa linguagem que ao invés de estar a seu favor, a sua disposição, se coloca contrária, adversa, possibilitando, tão somente, na mesma linha do ruído sonoro, a produção daquilo que Deleuze e Guattari vão chamar de gagueira linguística. Ressalta-se que o termo gagueira linguística se trata de um conceito positivo e de resistência, inclusive à própria noção de identidade que assujeita, que homogeneíza e apaga as singularidades, conforme menciona Deleuze; Guattari (2011): “Gaguejar é fácil, mas ser gago da própria linguagem é uma outra coisa, que coloca em variação todos os elementos linguísticos, e mesmo os não linguísticos, as variações de expressão e as variações de conteúdo [...]”. (DELEUZE; GUATTARI, 2011, p.45).

Destarte, parece mesmo óbvio um uso menor, desarranjado da língua que a faz produzir alterações infindas, dando ao sujeito uma sensação de não pertencimento, "E... e... e... Sempre houve uma luta na linguagem entre o verbo "ser" e a conjunção "e", entre "é" e "e"”". (DELEUZE; GUATTARI, 2011, p. 45, grifos do autor). Há mesmo, em toda a obra essa carência de palavras persuasivas e de poder advindas dos personagens, objetando-se a esse quadro, encontra-se modestas expressões e abundantes gestos de mudez, será que este silêncio também fala?

A coletividade da obra está estruturada em treze capítulos, por eles nos deparamos com uma narrativa que revela: um solo seco, um homem seco, uma vida seca; a banalização das vítimas da seca; a humanização do animal e a animalização do homem; a perspectiva de vida nova no último capítulo que tem o título de Fuga.

Nessas situações enunciadas pelos capítulos da obra, Ramos vai fotografando a vida do retirante nordestino, exposto as mazelas da opressão social, a perda de território e de sua história. Ele pronuncia o nordeste como uma região de destaque em sua escrita, queixando-se da seca e das condições de sobrevivência como intempéries daquelas paisagens, contudo por meio de sua palavra expressando um realismo crítico de forte apelo social e ideológico, um aceno, como no último capítulo, para a continuação do combate, da resistência revolucionária 
que traga a mudança almejada, como no pensamento de Bakhtin (2014, p. 99, grifos do autor): "A palavra está sempre carregada de um conteúdo ou de um sentido ideológico vivencial." Registrando ainda que: “A língua, no seu uso prático, é inseparável de seu conteúdo ideológico ou relativo à vida".

Para Kiffer (2002) a fome, a sede, a pobreza, a própria hostilidade imposta pelo meio, aproxima essa família da existência animal. Apresenta, o autor, um cenário de hostilidade. Os filhos do casal sequer tinham uma identidade própria, são sujeitos sem nome - um traço fundamental na constituição identitária, paradoxalmente, a cadela Baleia, ganha esse traço, além de afeto.

Ao dar nome tão grandioso à cachorra e não nomear os filhos do casal, Graciliano já indica certa aspereza nesse universo. Isso porque, como se sabe, o medo de que as crianças não sobrevivessem à fome e miséria do sertão brasileiro fazia com que inúmeras famílias simplesmente não dessem nome aos seus filhos (KIFFER, 2002, p. 2).

Pode-se considerar também a curiosidade do menino mais velho que deseja saber o significado da palavra inferno e tem a frustração como resposta, uma vez que a mãe não alcança tal significação, embora viva com exatidão seu sentido denotativo. Ainda aqui se registra o poder da palavra, o sentimento de gagueira em relação à sua língua, o dissabor desse assujeitamento que lhe proíbe um dizer, lhe impõe um silêncio, aprisiona o humano e seu desejo de saber as coisas do mundo.

\section{Resultados - para além das vidas secas, resistência}

O discurso denunciador da falta de atenção às famílias que convivem com a seca, evidencia momentos de aflição e sofrimento a que foram submetidas, mostra também o abuso dos que tinham alguma forma de poder político e se acovardaram sob diferentes pretextos, negando o direito a condições mais dignas de vida. Para Fabiano e sua família, nessa conjuntura, restam poucas alternativas, uma vez que a seca volta trazendo consigo toda espécie de tormento. A angústia e o medo também surgem como consequência de uma experiência outrora sentida, mas para além das vidas secas, apesar das incertezas, a esperança ressurge como potência que move aquela família.

Pouco a pouco uma vida nova, ainda confusa, se foi esboçando. Acomodar-se-iam num sítio pequeno, o que parecia difícil a Fabiano, criado solto no mato. Cultivariam um pedaço de terra. Mudar-se-iam depois para uma cidade, e os 
meninos frequentariam escolas, seriam diferentes deles. Sinhá Vitória esquentavase. Fabiano ria, tinha desejo de esfregar as mãos agarradas à boca do saco e à coronha da espingarda de pederneira. (RAMOS, 2011, p.127, grifo do autor).

A esperança é o fio condutor do recomeço na obra Vidas Secas, mediante todos os desafios, novos olhares são construídos e impulsionam tomadas de decisão que refletem a resistência em meio ao caos. Este é um traço forte da obra que, acima de qualquer dano vivido, ainda ecoa no presente, revelando a sempre perene fortaleza do povo nordestino diante das demoradas agonias causadas pela seca, pelos preconceitos e estereótipos, pelas "tristes partidas" daqueles que ainda deixam sua terra por falta de oportunidades.

Seca, preconceitos, estereótipos são elementos de conteúdo significativo, são palavras de ordem que servem a um poder, palavras de uma língua maior, invariante, territorializante. É necessário, então, buscar a fuga/resistência e não a morte diante da sentença dessas palavras, tomar os percalços e pré-juízos como uma potência, instrumento de forças contra as condições impostas.

Pois a questão não era: como escapar à palavra de ordem?, mas como escapar à sentença de morte que ela envolve, como desenvolver a potência de fuga, como impedir a fuga de se voltar para o imaginário, ou de cair em um buraco negro, como manter ou destacar a possibilidade revolucionária de uma palavra de ordem? (DELEUZE; GUATTARI, 2011, p.61-62).

Assim, a palavra esperança é empoderamento que nasce como potência, é insurreição, forma de a vida ser mais forte que a morte, é a indignação contra qualquer opressão que transborda e queima o peito, marcando um tempo novo de rupturas, de transformação em que a seca e outras crueldades sociais, econômicas, culturais, linguísticas são vividas, sentidas e enfrentadas na dimensão humana e não brutalizada. Na palavra de ordem, a vida deve responder a morte, não fugindo, mas fazendo com que a fuga aja e crie. (DELEUZE; GUATTARI, 2011, p. 62).

A obra Vidas Secas, de Graciliano Ramos, ainda ecoa no contemporâneo e inspirou uma proposta de intervenção pedagógica de leitura, de ação, de recriação e construção de sentidos, desenvolvida na Escola Estadual de Ensino Fundamental e Médio Bernardino José Batista Triunfo - Paraíba, sertão nordestino, com o título: Seca, Xote e Baião, desenvolvida com alunos da disciplina de Língua Portuguesa do ensino médio, sob a nossa orientação. 
Dessa forma, a partir da leitura da obra e do reconhecimento das raízes, os alunos se voltaram para a questão da seca, questionando-a como um fenômeno não apenas natural, e assim ressignificaram conteúdos, buscaram entender as formas de tratamento dessa questão em nível nacional, bem como as formas de convivência com esta realidade adversa, ambígua e díspar. Mas não foi apenas a obra Vidas Secas que serviu de materialidade para esta proposta de estudos, mas também o que foi contado e cantado por Luiz Gonzaga (poeta nordestino) em sua discografia, possibilitando um mergulho na cultura local e presente no que se leu e se viveu.

Nesse ponto, propõe-se trazer aqui, reverberando a discussão da obra Vidas Secas, a produção desses alunos reproduzida em nível local, no livro Retalhos Poéticos da Seca, como atividade integrante do projeto e disponível na biblioteca da escola. Foram eleitas duas materialidades discursivas, pelo critério discursivo de marcas de repetibilidade que aparecem nas demais materialidades produzidas e que se referem a dois momentos diferentes do projeto: o primeiro quando os alunos fizeram releitura da obra Vidas Secas e escreveram poesias e o segundo quando recriaram, na zona rural do município, os capítulos do livro em fotografias, visando à montagem de cenas para a realização de uma fotonovela.

Primeira Materialidade Discursiva:

Meu nome é Nordeste

Sou da Seca!

Se o desprezo comove?...

Eu sou forte e verdadeiro.

Apesar de sentir fome,

Sou do nordeste brasileiro.

(ROSENDO, 2012, p.34) 
Segunda Materialidade Discursiva:

Figura 1 - Reprodução de cena do livro Vidas Secas.

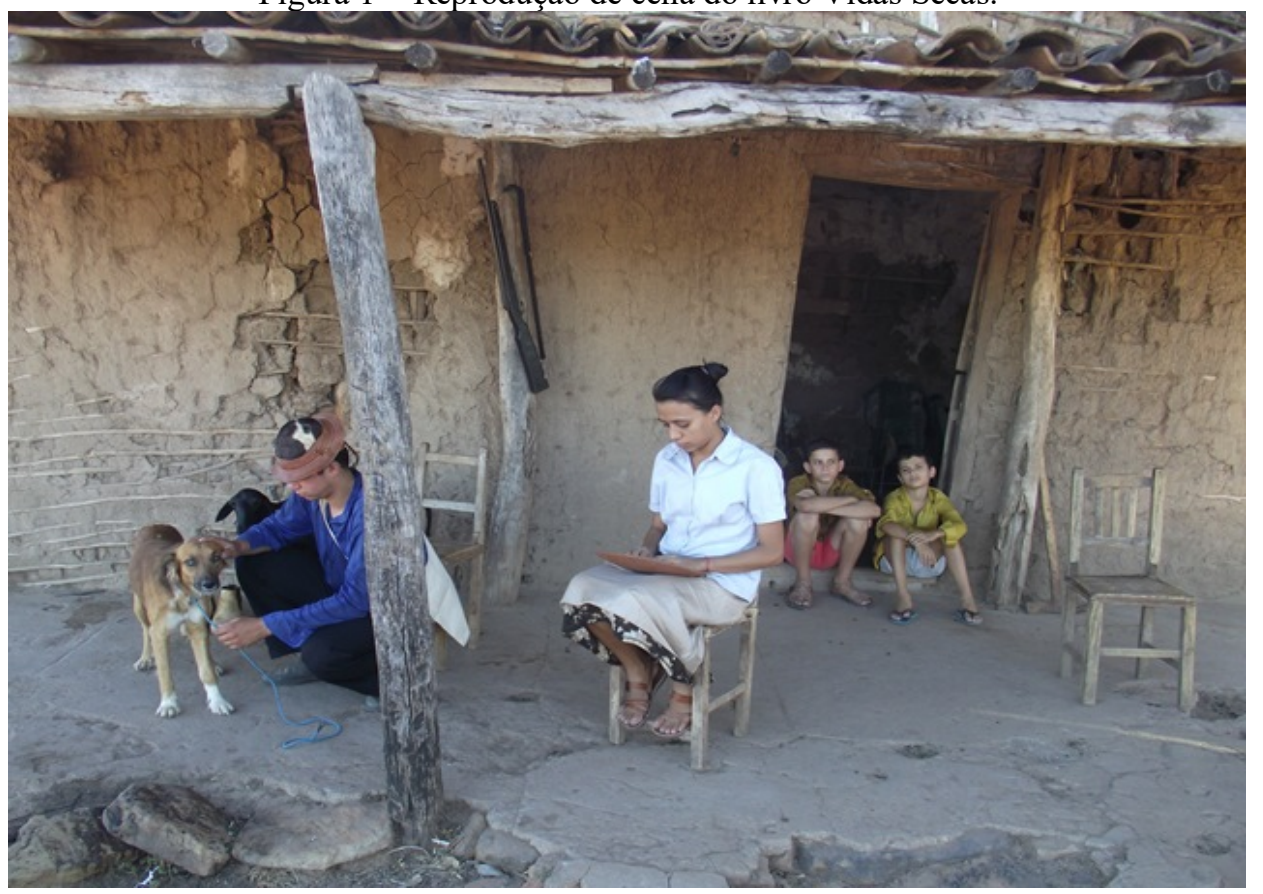

Fonte: Nozicássio Gomes de Oliveira (2012). Arq. pessoal colaborador do Projeto Seca, Xote e Baião.

Imprescindível justificar o emprego do termo materialidade discursiva a partir do enfoque da Análise de Discurso (AD) que trata o texto como uma unidade de análise, (como uma materialidade discursiva), na qual a memória ganha corpo, segundo Orlandi (2006). Nesse mesmo enfoque da $\mathrm{AD}$, ao trabalhar essas materialidades não se pretende analisar seu conteúdo, todavia além de ilustrar a atualização da obra Vidas Secas, na ótica dos alunos nordestinos em questão, buscar-se-á uma “compreensão de como estes objetos simbólicos produzem sentidos" (ORLANDI, 2015, p. 24).

O termo memória esteve sempre presente no desenvolvimento do projeto, como filhos daquelas terras, os alunos nas leituras e nos gestos de escrita rememoraram as lutas contra a miséria e a servidão, as demoradas agonias, de seus pais e familiares, de anos de repetição do fenômeno da seca, dos sonhos coletivos de se ver chegar às águas do Rio São Francisco, como maneira de aplacar os efeitos da estiagem. Assim, inseridos naquela historicidade, os alunos recordaram o que outrora foi dito, para poder saber dizer também e se reescreverem na história. Para Pêcheux "as palavras, as expressões, proposições, etc., mudam de sentido segundo as posições sustentadas por aqueles que as empregam" (PÊCHEUX, 1988, p.160, grifos do autor). 
Nesse ponto, ele relaciona o sentido com as posições inscritas na ordem das formações ideológicas.

Averígua-se pela análise dessas materialidades que as formações ideológicas estão desempenhando a função de reprodução das relações de produção, pelo movimento de sujeição que marca o sujeito ideológico, e dá a posição desse sujeito nessa historicidade. Dessa forma, é pelo "todo complexo das formações ideológicas" que se chega à concepção de formação discursiva (FD): “[...] aquilo que, numa determinada formação ideológica dada, isto é, a partir de uma posição dada numa conjuntura dada, determina pelo estado da luta de classes, o que pode e deve ser dito [...]”. (PÊCHEUX, 1988, p. 160, grifo do autor).

Os efeitos de sentidos produzidos nas duas materialidades - a poesia, e a fotografia se estabelecem a partir das FDs dominantes nos discursos em que se inscrevem os sujeitos- alunosprodutores, marcados historicamente pelas dificuldades econômicas e sociais, pelos sofrimentos da vivência com a seca, igualmente pelos pré-conceitos em torno dessa situação. Ou seja, o dito e o não dito ${ }^{2}$ nessa produção se compondo "nas relações que tais palavras, expressões ou proposições mantêm com outras palavras [...] da mesma formação discursiva". (PÊCHEUX, 1988, p.161).

É importante, nesse aspecto, o que escreve Indursky (2011, p. 82): “é o indivíduo que, interpelado pela ideologia, se constitui como sujeito, identificando-se com os dizeres da formação discursiva que representa, na linguagem, um recorte da formação ideológica". Pêcheux depreende que a interpelação do indivíduo em sujeito se dá pelo processo da identificação desse sujeito com a FD que o domina.

Uma marca que chama a atenção na poesia é a repetição do verbo ser, como uma reiteração de um sentimento de pertencimento, de íntima relação entre o sujeito e o verbo. Essa é uma marca de expressão forte, de harmonia com os dizeres da FD, que mobiliza pelo interdiscurso os pré-construídos e a memória ${ }^{3}$ e que permitem estes dizeres em detrimento de outros; dizeres carregados de sentidos, exatamente por já estarem inscritos e já constituírem sentidos em outro lugar, em outro momento, se reescrevendo em outros saberes e reconfigurando a FD.

\footnotetext{
${ }^{2}$ A formação discursiva é responsável por sustentar várias posições sujeito.

${ }^{3}$ Indursky (2011) explica que uma característica essencial da noção de memória para a AD é o fato do sujeito, ao produzir seu discurso, realiza-lo sob o regime da repetibilidade, mas o faz afetado pelo esquecimento, na crença de ser origem daquele saber.
} 
Assim, pela memória discursiva esse sujeito do discurso traz à tona os saberes sobre o ser nordestino, o ser da seca e do imaginário que carrega a noção de força e resistência desses brasileiros diante das contradições e intempéries da vida a exemplo do - "Eu sou forte e verdadeiro", registrado na poesia. E, desse conhecimento, pelo viés político da denúncia, o seu dizer bate com a realidade experimentada no passado, no presente (no futuro?) como uma marca da resistência, produzindo nas materialidades efeitos de sentidos para além da paráfrase, uma vez que amplia pela vivência e pela "livre" interpretação os efeitos da polissemia, ainda que contida, dado a inscrição dessas materialidades no discurso autoritário.

$\mathrm{Na}$ fotografia, constata-se que ela também está inscrita nessa situação discursiva, uma vez que ela foi produzida depois da leitura, do debate e da escrita de poesia, a partir de sequências da narrativa da obra literária Vidas Secas. Assim, na cena em destaque é possível descrever/interpretar considerando, inicialmente, a precária moradia erguida com barro e desprovida de qualquer condição estrutural sobre a qual se posicionam quatro pessoas e dois animais: ao centro se coloca a mulher que lembra a figura da personagem Sinhá Vitória. Ela está sentada, numa posição curvada e traz consigo um olhar sério e compenetrado naquilo que faz, como que alheia a tudo que está a sua volta, inclusive aos filhos; à direita estão o homem que representa Fabiano e a cachorra que remonta Baleia, também personagens do Vidas Secas, além de um cabrito. O homem agachado faz um carinho no animal, manifestação que nos gestos de interpretação revela a humanização do animal, único membro da família que recebia afagos e era bem tratado; os filhos aparecem ao fundo da fotografia. Estão sentados junto à porta, expressando uma tristeza visível, um desencantamento e uma apatia a tudo que lhes cerca. Ferramentas de trabalho também aparecem, como a espingarda e a picareta trazendo a ideia da labuta diária, do suor pela sobrevivência. No conjunto dessa materialidade significante há a ideia de abandono e indiferença impressa, em que muita coisa é dita, mas também muita coisa é silenciada.

Dessa maneira, os efeitos de sentidos produzidos na fotografia estão limitados. Isso sugere uma paráfrase, por manter certo dizer repetido pela obra, pela poesia, pelo discurso do cotidiano, ou seja, uma volta aos lugares enunciativos já marcados com forte repetibilidade da matriz de sentidos, e embora a textualidade seja diferente, há em comum atravessamentos que constituem essas materialidades, o que as fazem discursos.

É possível notar que pelo funcionamento da memória se tem regularidades que levaram à manutenção, ou melhor, à certa estabilização dos sentidos. Mas conforme afirma Indursky 
(2011), essa repetição também leva a um deslizamento, a uma ressignificação, à ruptura com o regime de regularização dos sentidos, nesse caso marcadamente se teria a contra identificação, não evidenciada nas duas materialidades analisadas.

As condições de produção e de circulação estão envoltas nessas circunstâncias, bem como a historicidade e o ideológico que determinam o lugar discursivo na relação com a formasujeito e a posição-sujeito. Percebe-se uma aderência quase completa em relação ao discurso do outro, já posto, já dado, e que firma a posição sujeito com a sua formação discursiva, reafirmando estes dizeres com pertencimento e como se estes fossem seus originalmente, função do esquecimento número 1 .

Por fim, assinala-se que nessa relação de sujeitos produtores de linguagem é possível tomar lugares de identificação, ou os seus contrários, o que em cada caso seria uma espécie de atravessamento espelhando a condição humana do indivíduo relacionada com a ideologia.

\section{Considerações finais}

Pela linguagem o homem vai se constituindo sujeito, ainda que ela o classifique, o diferencie, marcando-o socialmente em posições e identificando-o numa relação de submissão, pois fora dela não há lugar: "A linguagem não é a vida, ela dá ordens à vida; a vida não fala, ela escuta e aguarda" (DELEUZE; GUATTARI, 2011, p.13).

Desse modo, não há liberdade de escolha, uma vez que não há o extrínseco da linguagem, e não se trata de restrição ao princípio da liberdade, mas negação à sua existência, pois num sistema de normas fechadas, incorrer no abuso de renegá-las é ser o indivíduo da margem, trilhar por um caminho "impossível da anarquia linguageira".

A incoerência é propiciada pelas estruturas do poder que estão na base da linguagem, e submetem o indivíduo usuário da língua a regimes que se polarizam entre a servidão e o poder; regimes que segregam e servem para intimidar. Por conseguinte, como forma de escapismo dessa lógica se apresenta a literatura, espaço de liberdade, como diz Barthes (1996) permitindo delatar as injustiças sociais, na realidade concreta da vida.

Vidas Secas como drama do ontem (1938) tem ressonância no hoje, uma vez que a estiagem ainda é uma realidade angustiante, contudo nos movimentos de interpretação e de ação do homem que atravessa essas dificuldades, a resistência se dá para além da sobrevivência, se firmando como um gesto de subjetivação política, poder maior contra qualquer dominação. 
Pelo que precede, conclui-se que em relação à análise empreendida os sentidos alcançados se dão na repetibilidade de uma matriz de sentidos, e isso tem relação com a paráfrase, o que caracterizou um acontecimento enunciativo, fato possibilitado pela mobilização da memória como pré-construído alcançando a produtividade, muito mais que a criatividade.

\section{Referências}

ABEL, C. A. dos S. Graciliano Ramos: cidadão e artista. Brasília: Editora Universidade de Brasília, 1999.

ARISTÓTELES. Política. Trad. Pedro Constatin Tolens. São Paulo: Martins Claret, 2001.

BAKHTIN, M. Marxismo e filosofia da linguagem. São Paulo: Hucitec, 2014.

. (VOLOCHINOV). Marxismo e filosofia da Linguagem. Trad. e Org. Michel Lahud e Yara Frateschi Vieira. São Paulo: Annablume; Hucitec, 2002.

BARTHES, R. Da ciência à literatura; A guerra das linguagens; A divisão das linguagens. In: O rumor da língua. São Paulo: Martins Fontes, 2004.

. Aula. São Paulo: Cultrix, 1996.

BRASIL. Lei Federal $\mathbf{N}^{\circ} \mathbf{1 7 5}$ de 28 de Julho de 1936. Disponível em:

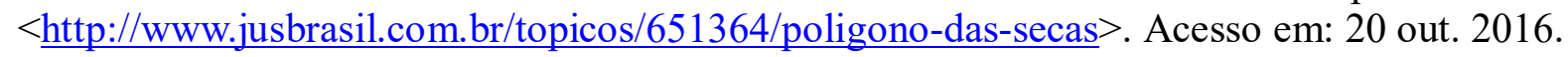

DEleuZE, G.; GUATTARI, F. Mil Platôs - Capitalismo e esquizofrenia 2. São Paulo: Ed. 54, 2011.

INDURSKY, F. Da interpelação à falha no ritual: a trajetória teórica da noção de formação discursiva. In: BARONAS, R. L. (Org.). Análise de Discurso: Apontamentos para uma história da noção-conceito de formação discursiva. 2. ed. rev. e ampl. São Carlos: Pedro \& João Editores, 2011.

JAKOBSON, R. Linguística e comunicação. 20a ed. São Paulo: Pensamento-Cultrix, 2005.

LÉVI-STRAUSS, C. Mitológicas I. O cru e o cozido. Rio de Janeiro: Cosac e Naify, 2004.

KIFFER, A. P. V. Vidas Secas: ontem e hoje. Disponível em: http://www.letras.pucrio.br/unidades\&nucleos/janeladeideias/biblioteca/B_Literatura_Memoria.pdf. Acesso em: 20 de outubro de 2016.

MARX, K. Contribuição à crítica da economia política. 2. ed. São Paulo: WMF Martins Fontes, 2003. 
ORLANDI, E. Análise de discurso: princípios e procedimentos. Campinas. Pontes, 2015. . Análise de discurso. In: ORLANDI, E.; LAGAZZI-RODRIGUES, S. (org.) Discurso e Textualidade. Campinas. Pontes, 2006.

PÊCHEUX, M. Semântica e discurso. Campinas: Editora da Unicamp, 1975[1988].

RAMOS, G. Vidas secas. Posfácio de Hermenegildo Bastos. 115. ed. Rio de Janeiro: Record, 2011.

RANCIÈRE, J. O dano: política e polícia. In: O desentendimento: política e filosofia. Trad. Ângela Leite Lopes. São Paulo: Ed. 34, 1996.

ROSENDO, T. M. (org.). Retalhos poéticos da seca. 2012. 46p. Biblioteca Esc. Est. E.F.M. Bernardino José Batista - Triunfo/PB.

ROUSSEAU, J-J. Ensaio sobre o entendimento das línguas. 2. ed. São Paulo: Abril Cultural, 1978. (Coleção Os Pensadores). 